\title{
ANALISIS PENINGKATAN KINERJA KUALITAS DAYA LISTRIK TEGANGAN 20 kV DI INDUSTRI BERBASISKAN SIMULASI ETAP 12.6.0
}

\author{
Anto Carmanto \\ Prodi Teknik Elektro UNPAM \\ Jln. Puspiptek Raya No 46 Buaran, Setu - Tangerang Selatan 15310 INDONESIA
}

Email:dosen01312@unpam.ac.id

\begin{abstract}
ABSTRAK
Kualitas energi listrik yang baik di industri selain akan menghasilkan produk yang maksimal, kualitas energi listrik yang baik juga dapat membuat peralatan listrik yang ada di industri akan lebih awet. Penelitian ini dilakukan untuk meningkatkan kinerja kualitas daya listrik pada tegangan $20 \mathrm{kV}$ di industri guna memperbaiki rugi-rugi daya, tegangan jatuh, faktor daya dan perbaikan tegangan transien. Setelah melihat performa jaringan Tegangan $20 \mathrm{kV}$, Selanjutnya dilakukan perbaikan supaya performa jaringan lebih maksimal. Pengambilan data yang sebenarnya pada tegangann $20 \mathrm{KV}$ (tegangan menengah) dilakukan pada penelitian di industri ban yang berkapasitas 30,250 MVA. Analisa data menggunakan perangkat lunak ETAP12.6.0. Hasil analisis menunjukan adanya penurunan rugi-rugi daya sebesar $52,3 \%$ apabila dibandingkan jaringan eksisting. Hasil analisis juga menunjukan adanya penurunan tegangan jatuh sebesar $45,6 \%$ apabila dibandingkan jaringan eksisting. Faktor daya juga mengalami perbaikan setelah penambahan kapasitor bank. Faktor daya mengalami perbaiakan/kenaikan sebesar 7,95\%. Tegangan yang mengalir saat terjadi transien di bus 2 mengalami penurunan sebesar $47,4 \%$ setelah penambahan reaktor. Tegangan yang mengalir saat terjadi transien di bus 4 juga mengalami penurunan sebesar $542.8 \%$ setelah penambahan reaktor.
\end{abstract}

Kata Kunci: ETAP, Kualitas Energi Listrik

\begin{abstract}
Analysis of Improving The Quality Performance of $20 \mathrm{kV}$ Voltage Power In Industry Based On Simulation of ETAP 12.6.0. The quality of electrical energy that is good in the industry besides producing maximum products, the quality of good electrical energy can also make electrical equipment in the industry more durable. This research was conducted to improve the performance of electrical power quality at a voltage of $20 \mathrm{kV}$ in the industry to improve power losses, voltage drops, power factors and repair of transient voltages. After seeing the network performance of the $20 \mathrm{kV}$ voltage, further improvements are made so that network performance is maximized. The actual data retrieval at a voltage of $20 \mathrm{KV}$ (medium voltage) is carried out in the tire industry with a capacity of 30,250 MVA. Data analysis using ETAP12.6.0 software. The results of the analysis show a decrease in power losses of 52.3\% compared to the existing network. The results of the analysis also showed a decrease in voltage falling by $45.6 \%$ compared to the existing network. The power factor also improved after the addition of bank capacitors. The power factor experienced an increase / increase of $7.95 \%$. The voltage flowing during transients on bus 2 has decreased by $47.4 \%$ after the addition of the reactor. The voltage flowing during transients on bus 4 also decreased by $542.8 \%$ after the addition of the reactor.
\end{abstract}

Keyword: ETAP, Power Quality 


\section{PENDAHULUAN}

$\mathrm{K}$ ualitas energi listrik yang baik di industri selain akan menghasilkan produk yang maksimal, kualitas energi listrik yang baik juga dapat membuat peralatan listrik yang ada di industri akan lebih awet. Oleh karena itu perlu adanya analisis/kajian serta Terobosan-terobosan yang dapat memaksimalkan kualitas energi listrik, salah satunya dengan menggunakan simulasi perangkat lunak ETAP 12.6.0.

Kualitas instalasi jaringan akan terlihat dari kontinuitas suplai listrik ke beban. Untuk naik turunnya tegangan yang diperbolehkan $\pm 5 \%$, Apabila batas tegangan normal dapat dikendalikan, maka akan menetukan kualitas daya yang disuplai ke beban, sehingga resiko kerusakan pada peralatan listrik juga bisa dihindari atau dapat diminimalkan.

\section{TEORI}

\section{Stabilitas Sistem Tenaga Listrik}

Stabilitas sistem tenaga listrik adalah kemampuan sistem tenaga listrik untuk mempertahankan besar tenaga listrik yang ada, selalu dalam keadaan normal.

Kualitas power yang bermasalah merupakan persoalan perubahan bentuk frekusensi, tegangan, dan arus yang dapat mengakibatkan kegagalan peralatan, baik peralatan milik PLN maupun milik konsumen, Kualitas Power yang bermasalah bisa merugikan PLN maupun konsumen.

Konsumen harus mendapatkan pelayanan terbaik dalam sistem tenaga listrik, diantaranya[8]:

1. Beban puncak dapat terpenuhi.

2. Memiliki deviasi tegangan dan frekuensi yang minimum.

3. Urutan phase yang benar.

4. Distorsi gelombang harmonik dan tegangan yang minimum.

5. Bebas dari surja tegangan.

6. Setimbangnya suplai tegangan.

Sistem Pemrograman ETAP 12.6.0

ETAP kepanjangan dari Electric Transient and Analysis Program adalah suatu software yang digunakan dalam sistem tenaga listrik untuk membuat simulasi saat atau sebelum melakukan perancangan yang digunakan untuk menganalisa sistem jaringan mulai dari pembangkit, sistem transmisi, sistem distribusi sampai dengan ke beban.

\section{Rugi-Rugi Daya Pada Jaringan Tegangan Menengah}

Jaringan yang dilewati daya listrik dari pembangkit sampai dengan konsumen dilakukan perbaikan guna mengurangi rugi-rugi daya.

Pengaruh tegangan terhadap rugi-rugi daya adalah semakin besar tegangan pada suatu saluran/jaringan, maka semakin kecil arus pada saluran/jaringan tersebut. Arus juga merupakan salah satu faktor yang mempengaruhi besar kecilnya rugi- rugi daya pada suatu saluran/jaringan. Seperti yang terlihat pada rumus berikut ini:

$$
P=I^{2} \cdot R
$$

Dimana:

$\mathrm{P}=$ Rugi-rugi daya (Watt)

$\mathrm{I}=$ Kuat arus listrik (Ampere)

$\mathrm{R}=$ Hambatan (Ohm)

\section{Tegangan Jatuh}

Tegangan jatuh adalah besarnya tegangan yang hilang pada suatu penghantar. Tegangan Jatuh pada saluran tenaga listrik selaras dengan dengan panjang saluran dan beban dan berlawanan dengan luas penampang penghantar [6]. Besarnya tegangan jatuh dinyatakan baik dalam persen maupun dalam besaran Volt. Besarnya toleransi maksimal dan minimalnya ditentukan oleh kebijaksanaan perusahaan kelistrikan. Semakin besar luas penampang penghantar yang digunakan, maka semakin kecil kerugian tegangan atau tegangan jatuh yang terjadi. Rumus untuk menghitung besarnya kerugian tegangan atau tegangan jatuh pada instalasi listrik phase 3 [3].

$$
V_{r}=\frac{(\sqrt{3} x \rho \times L \times I \times \operatorname{Cos} p h i)}{A}
$$

Vr : Tegangan jatuh (Drop Voltage) 


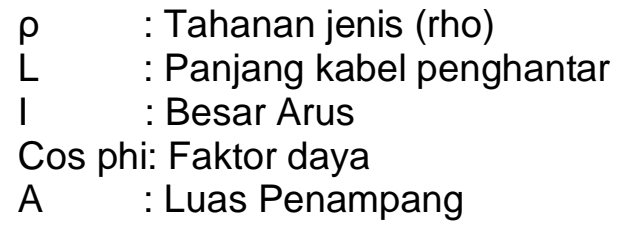

\section{Faktor Daya}

Suatu alat yang digunakan untuk memperbaiki faktor daya adalah kapasitor bank. Kapasitor bank adalah sekumpulan kapasitor yang dihubungkan paralel dengan rangkaian beban. Elektron akan mengalir masuk ke kapasitor bila rangkaian itu diberi tegangan. Pada saat kapasitor penuh dengan muatan elektron maka tegangan akan berubah. Kemudian elektron akan keluar dari kapasitor dan mengalir ke dalam rangkaian yang memerlukannya.
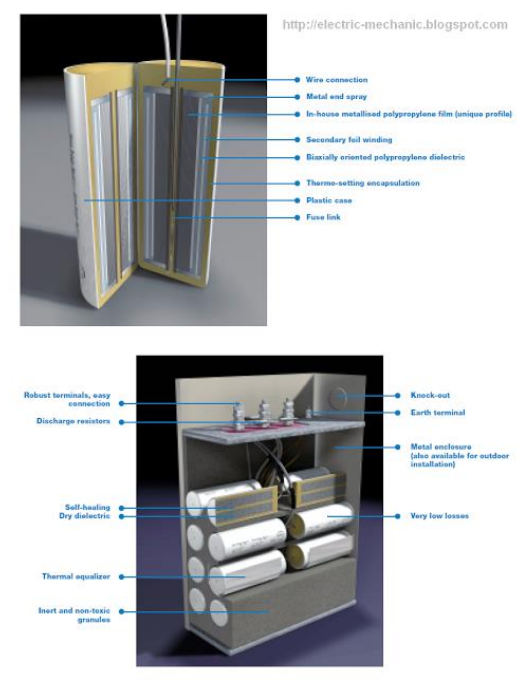

Gambar 1. Kapasitor Bank

\section{Transien Jaringan}

Transien elektrik yang terjadi pada sistem tenaga umumnya disebabkan oleh suatu perubahan tiba-tiba dalam kondisi pengoperasian atau konfigurasi dari sistem. Overvoltage transien ini disebabkan oleh petir yang menyambar saluran transmisi atau oleh operasi switching. Petir selalu berpotensi bahaya terhadap peralatan, begitu pula pengoperasian switching juga berpotensi merusak.

Saluran udara biasanya diproteksi dari petir oleh satu atau lebih kawat yang disebut kawat tanah yang ditempatkan diatas konduktor fasa. Kawat tanah dihubungkan ke tanah melalui menara transmisi. Dalam banyak kasus, petir menyambar kawat tanah sebagai ganti dari konduktor fasa.

Nilai puncak arus tergantung pada intensitas sambaran petir, atau nilai tipikal $10.000 \mathrm{~A}$ ke atas. Bila suatu konduktor fasa disambar oleh petir, kerusakan terhadap peralatan pada terminal saluran disebabkan oleh kelebihan tegangan sebagai hasil dari arus yang berjalan sepanjang saluran. Gelombang tegangan dan arus mempropagasi sepanjang saluran transmisi pada kecepatan mendekati kecepatan cahaya. Tipikal tegangan ini di atas sejuta volt. Ketika petir menyambar kawat tanah, surja tegangan tinggi juga diproduksi pada saluran transmisi oleh induksi elektrmagnetik. Peralatan pada terminal saluran diproteksi oleh arrester surja, yang disebut arrester petir. Arrester terhubung dari jaringan ke tanah.

\section{Analisa Stabilitas}

Karena daya listrik dalam suatu jaringan dihasilkan secara eksklusif oleh generator (mesin sinkron), salah satu kondisi dasar untuk suatu kesetabilan suplai daya listrik adalah sinkronisasi. Karena itu stabilitas sistem tenaga mengacu pada kemampuan mesin sinkron menjaga sinkronisasinya ketika bergerak dari titik operasi steady state menyusul suatu gangguan ke titik operasi steady state lain [5]. Suatu simplifikasi berdasarkan pada naluri sudah dibuat untuk membagi secara teori permasalahan stabilitas sistem tenaga.

Analisa stabilitas steady state menguji sistem dalam kondisi statik dengan derivatif waktu terhadap semua variabel menjadi nol. Dalam kondisi operasional ini berarti bahwa hanya perubahan sangat rendah yang diperbolehkan, sehingga derivatif waktu dapat ditiadakan, tetapi pengalaman operasional dalam sistem telah menunjukan bahwa beban sistem selalu cenderung berfluktasi dengan amplitudo kecil, yang dapat menghasilkan osilasi elektromekanikal yang tidak dikehendaki, kehilangan sinkronisasi generator, trip relai proteksi dsb, yang 
lebih lanjut dapat menyebabkan kondisi bahaya.

Analisa stabilitas menjadi sangat penting dalam perencanaan dan pengoperasian sistem untuk menjamin sekuriti sistem. Karakteristik stabilitas dari sistem tenaga selama gangguan transien dianalisa dari sifat kestabilan model matematik yang dipresentasikan oleh sejumlah persamaan.

\section{METODOLOGI}
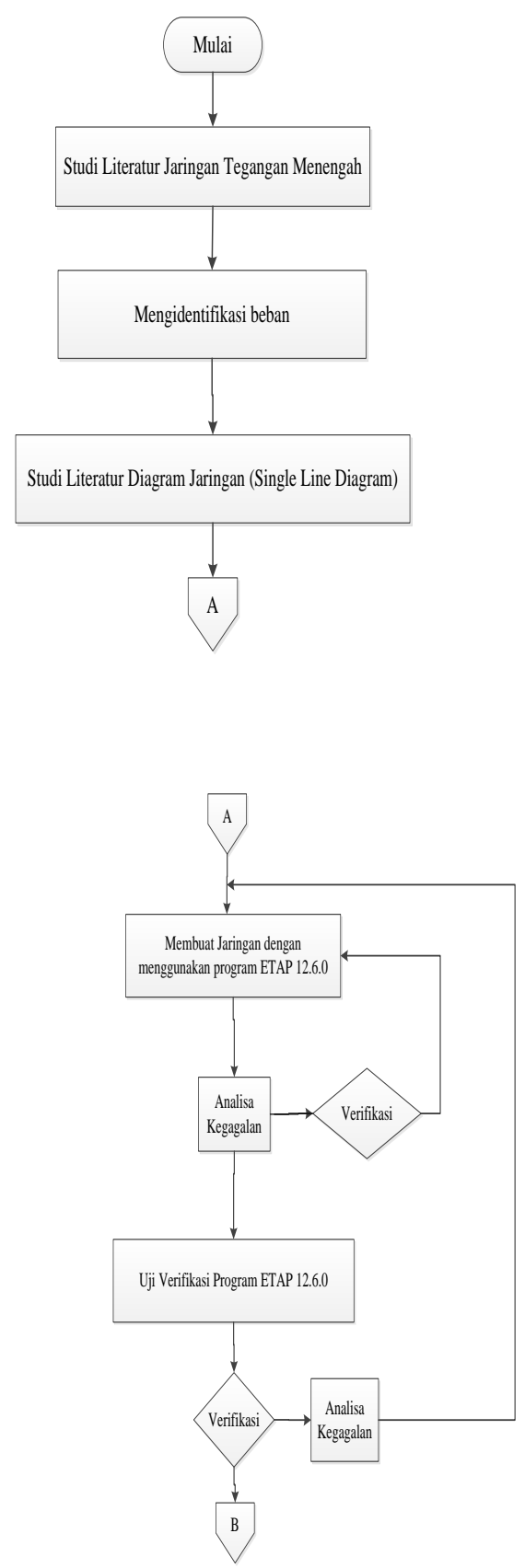

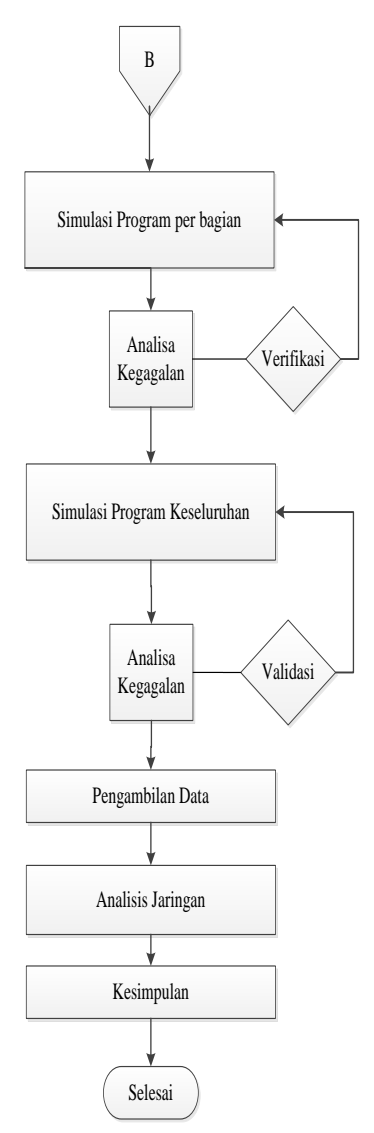

Gambar 2. Flow Chart Penelitian

Penelitian ini dilaksanakan dengan melakukan langkah-langkah sebagai berikut : langkah ke-1 yaitu studi literatur mengenai rugi-rugi daya, tegangan jatuh, faktor daya dan stabilitas transien. Langkah ke-2 adalah mengidentifikasi beban yaitu mengenai beban apa saja yang terpasang pada jaringan. Langkah ke-3 adalah mengetahui diagram jaringan yang akan diteliti. Langkah ke-4 adalah pembuatan simulasi jaringan menengah $20 \mathrm{kV}$ dengan menggunakan software ETAP 12.6.0. Langkah ke-5 adalah melakukan analisis jaringan.

\section{HASIL DAN PEMBAHASAN}

\section{Deskripsi Sistem Tenaga Listrik Tempat Penelitian}

Wilayah yang dijadikan penelitian adalah wilayah operasi tegangan $20 \mathrm{kV}$ pada instalasi jaringan tegangan menengah PT Gajah Tunggal plant $M$ 
dengan kapasitas 30,250 MVA yang di suplai oleh gardu distribusi KC 400. Plant M mempunyai 16 mesin mixer, terdiri dari 14 mixer yang sudah beroprasi dan 2 mixer dalam proses instalasi. Mesin mixer adalah mesin yang digunakan untuk menggiling campuran karet, karbon dan berbagai bahan kimia lainnya dan kemudian hasil produksi dari plant $M$ dijadikan bahan baku untuk membuat ban di setiap plant yang ada di PT Gajah Tunggal Tbk.

Tabel 1. Mesin Mixer Plant M

\begin{tabular}{|l|l|l|}
\hline Nama Mesin & $\begin{array}{l}\text { Beban } \\
(\mathrm{KW})\end{array}$ & Keterangan \\
\hline MCG 1 & 2500 & $\begin{array}{l}\text { Sudah } \\
\text { Beroprasi }\end{array}$ \\
\hline MCG 2 & 2500 & $\begin{array}{l}\text { Sudah } \\
\text { Beroprasi }\end{array}$ \\
\hline MCG 3 & 1650 & $\begin{array}{l}\text { Sudah } \\
\text { Beroprasi }\end{array}$ \\
\hline MCG 4 & 2500 & $\begin{array}{l}\text { Sudah } \\
\text { Beroprasi }\end{array}$ \\
\hline MCG 5 & 1750 & $\begin{array}{l}\text { Sudah } \\
\text { Beroprasi }\end{array}$ \\
\hline MCG 6 & 2500 & $\begin{array}{l}\text { Sudah } \\
\text { Beroprasi }\end{array}$ \\
\hline MCG 7 & 1700 & $\begin{array}{l}\text { Sudah } \\
\text { Beroprasi }\end{array}$ \\
\hline MCG 8 & 2500 & $\begin{array}{l}\text { Sudah } \\
\text { Beroprasi }\end{array}$ \\
\hline MCG 9 & 1700 & $\begin{array}{l}\text { Sudah } \\
\text { Beroprasi }\end{array}$ \\
\hline MCG 10 & 2500 & $\begin{array}{l}\text { Sudah } \\
\text { Beroprasi }\end{array}$ \\
\hline MCG 11 & 1750 & $\begin{array}{l}\text { Sudah } \\
\text { Beroprasi }\end{array}$ \\
\hline MCG 12 & 2500 & $\begin{array}{l}\text { Sudah } \\
\text { Beroprasi }\end{array}$ \\
\hline MCG 13 & 2500 & $\begin{array}{l}\text { Sudah } \\
\text { Beroprasi }\end{array}$ \\
\hline MCG 14 & 1700 & $\begin{array}{l}\text { Sudah } \\
\text { Beroprasi }\end{array}$ \\
\hline MCG 15 & & $\begin{array}{l}\text { Belum } \\
\text { Beroprasi }\end{array}$ \\
\hline MCG 16 & $\begin{array}{l}\text { Belum } \\
\text { Beroprasi }\end{array}$ \\
\hline Total Beban & 30250 & \\
\hline
\end{tabular}

Jaringan tegangan plant $M$ di suplai dari gardu distribusi KC 400, bisa dilihat pada gambar 3 .

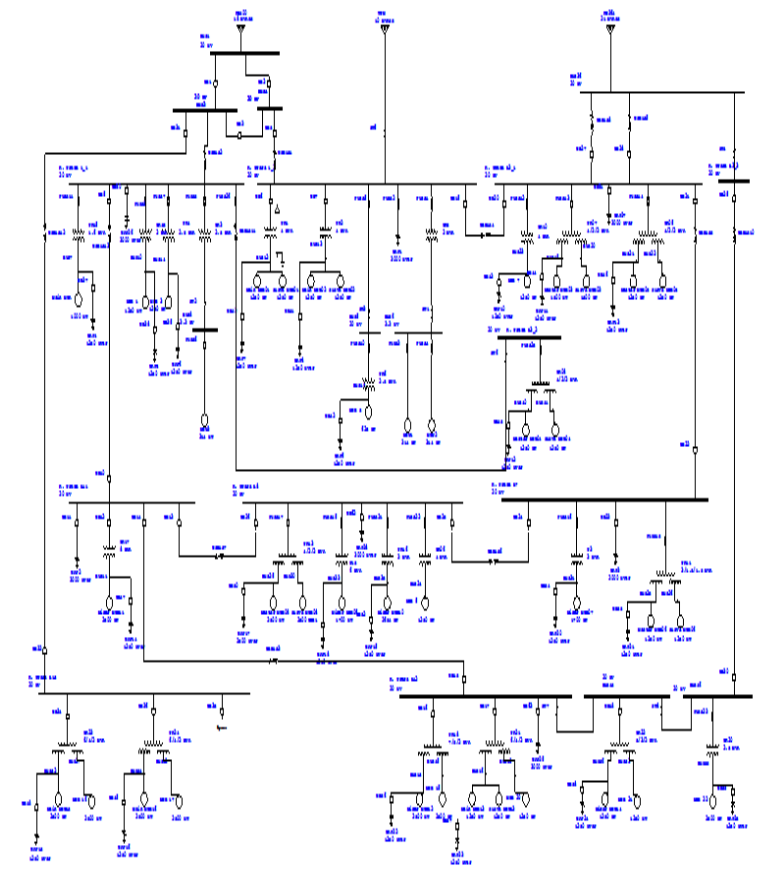

Gambar 3. Jaringan Instalasi 20 kV Existing

\section{Unjuk Kerja Jaringan Awal Menggunakan Alat Ukur Power Quality Analyzer}

Hasil pengukuran yang dilakukan pada tanggal 30 Mei 2017 ditemukan tegangan jatuh sampai dengan 16,75 kV dari beban normal $20 \mathrm{kV}$. Terjadi tegangan jatuh sebesar $16,25 \%$ selama 0,6 detik. Sedangkan tegangan yang di ijinkan sebesar $\pm 5 \%$ dari tegangan utamanya.

a. Pengukuran Tegangan Jatuh

Gambar 4 dibawah ini adalah hasil pengukuran tegangan pada instalasi jaringan tegangan $20 \mathrm{kV}$ plant $M$ dengan menggunakan alat ukur power quality analyzer merk hioki. 
$20 \mathrm{kV}$

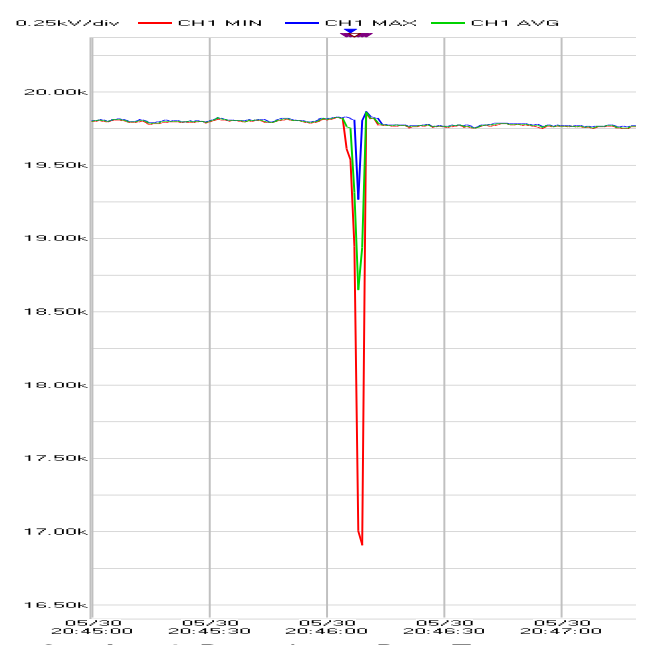

Gambar 4. Pengukuran Drop Tegangan

b. Pengukuran Arus

Arus yang mengalir dalam keaadaan normal di plant $M$ rata-rata sebesar 200 Ampere, tetapi saat terjadi gangguan, arus naik sampai dengan 337 Ampere. Ada kenaikan $68,5 \%$ dari arus normal. Seperti terlihat pada gambar 4.3.

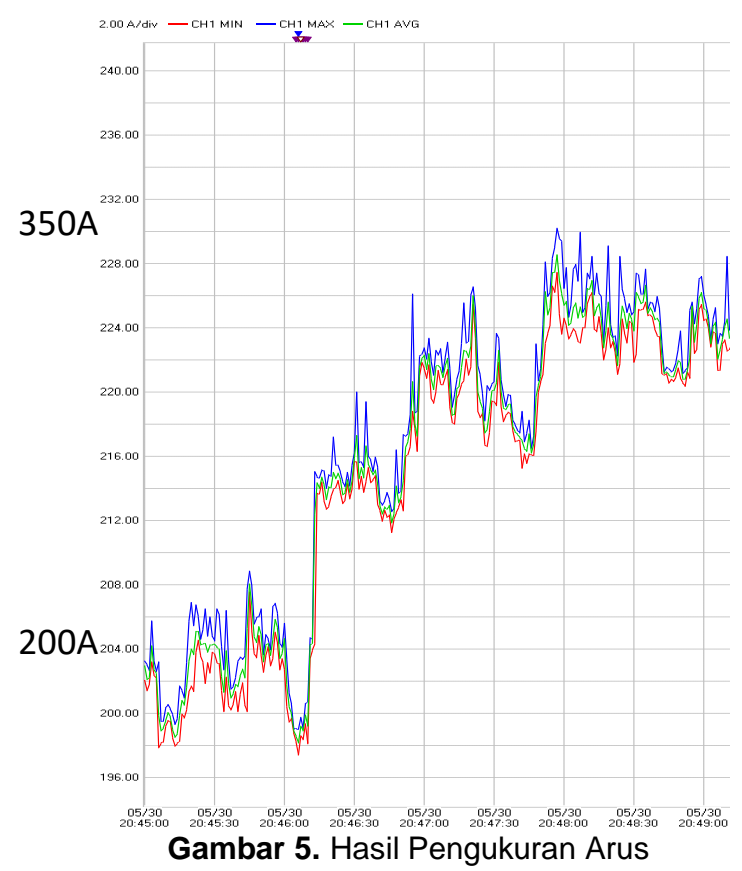

c. Pengukuran Faktor Daya

Faktor daya pada saat gangguan turun dari 0,96 menjadi 0,86 , ada penurunan $10,4 \%$ dari faktor daya sebelumnya.

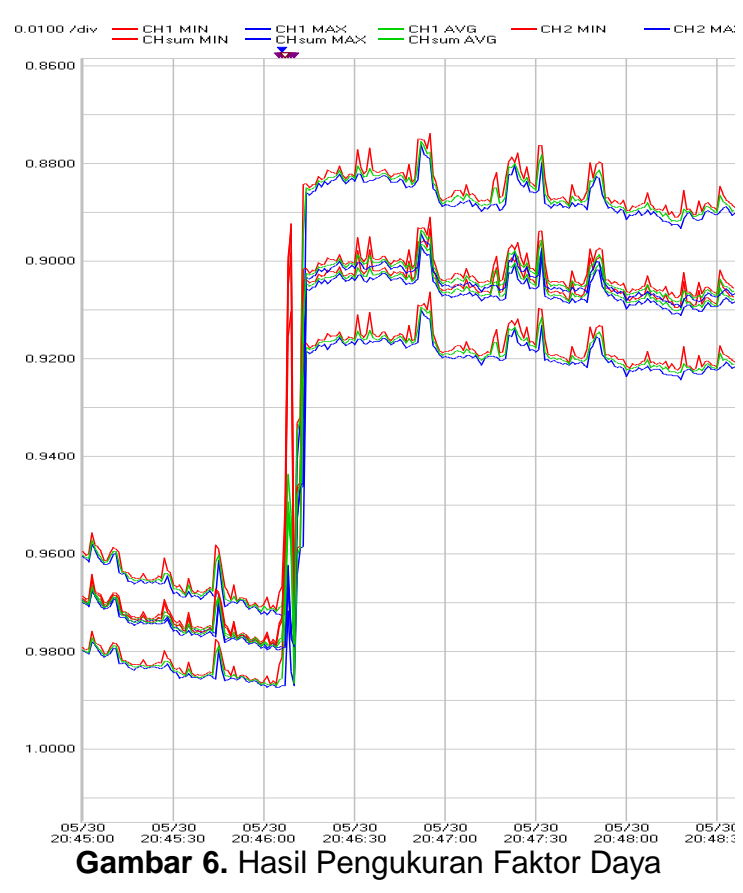

\section{Unjuk Kerja Jaringan Awal dengan Simulasi ETAP}

Unjuk kerja dengan menggunakan simulasi ETAP 12.6.0 dengan asumsi daya yang mengalir ke beban sebesar $40 \%$ diperlukan untuk mengetahui kualitas daya yang ada pada jaringan eksisting berdasarkan simulasi. Asumsi beban $40 \%$ diambil dari total beban saat beban jaringan $100 \%$ yaitu sebesar 30,250 MVA dengan menggunakan simulasi ETAP 12.6.0 dan asumsi beban $40 \%$ juga berdasarkan hasil pengukuran mengguankan alat ukur power quality analyzer. Dari hasil pengukuran jaringan eksisting dengan menggunakan power quality analyzer menunjukan daya yang mengalir pada jaringan sebesar 8,257 MVA.

\section{Kekurangan Sistem Eksisting}

Rugi-rugi daya pada sistem eksisting disebabkan oleh disipasi daya penghantar jaringan yang mengakibatkan panas pada jaringan penghantar tersebut, sehingga mengakibatkan rugi-rugi daya dan tegangan jatuh.

Statistik jumlah dan durasi gangguan dari bulan januari 2015 sampai dengan bulan April 2017 tercatat sebanyak 203 kali gangguan, dengan total durasi gangguan sebanyak 225,7 jam. Total kerugian PT Gajah Tunggal Tbk akibat 
gangguan sebesar Rp. 75,99 Milyar. Tabel dibawah ini adalah jumlah durasi gangguan dalam kurun waktu tahun 2015 sampai tahun 2017 (Sumber dari Departemen Utility PT Gajah Tunggal, Tbk.).

\section{Langkah-langkah Perbaikan Rugi-rugi Daya Dan Tegangan Jatuh}

Jaringan distribusi tegangan menengah 20 kV PT Gajah Tunggal Tbk plant $M$ akan di optimalkan kulitasnya. Kondisi jaringan tegangan menengah ini akan disimulasikan menggunakan perangkat ETAP 12.6.0 untuk mengetahui rugi-rigi daya dan tegangan jatuh.

Suatu model dapat dikatakan valid ketika tidak memiliki perbedaan yang berarti/mencolok dengan sistem nyata yang diamati. Gambar di bawah ini adalah contoh parameter jaringan eksisting yang dimasukan dalam program ETAP 12.6.0.

Tabel 1. Langkah Perbaikan Rugi-rugi Daya

\begin{tabular}{|c|c|c|c|}
\hline Nama Kabel & Type Penghantar $\left(\mathrm{mm}^{2}\right)$ & $\begin{array}{c}\text { Losses } \\
(\mathrm{kW})\end{array}$ & \%Vd drop in Vmag \\
\hline Cable 1 & Cu N2XSEBY (3X300) & 0.00 & 0.00 \\
\hline Cable 2 & Cu N2XSEBY (3X300) & 0.50 & 0.00 \\
\hline Cable 3 & Cu N2XSEBY (3X120) & 3.70 & 0.04 \\
\hline Cable 4 & Cu N2XSEBY (3X240) & 4.40 & 0.04 \\
\hline Cable 5 & Cu N2XSEBY (3X240) & 1.60 & 0.02 \\
\hline Cable 6 & Cu N2XSEBY (3X240) & 0.70 & 0.03 \\
\hline Cable 7 & Cu N2XSEBY (3X240) & 0.30 & 0.00 \\
\hline Cable 8 & Cu N2XSEBY (3X240) & 0.80 & 0.04 \\
\hline Cable 9 & Cu N2XSEBY (3X240) & 0.80 & 0.04 \\
\hline Cable 10 & Cu N2XSEBY (3X120) & 18.50 & 0.13 \\
\hline Cable 11 & Cu N2XSEBY (3X95) & 0.80 & 0.03 \\
\hline Cable 12 & Cu N2XSEBY (3X240) & 12.00 & 0.12 \\
\hline Cable 13 & Cu N2XSEBY (3X240) & 9.50 & 0.08 \\
\hline & Total & $\mathbf{5 3 . 6}$ & $\mathbf{0 . 5 7}$ \\
\hline
\end{tabular}

a. Perbaikan rugi-rugi daya dan tegangan jatuh.

Merubah ukuran kabel penghantar akan dilakukan untuk mengurangi rugi-rugi daya. Jaringan eksisting disimulasikan menggunakan perangkat lunak ETAP 12.6.0, setelah itu memasukan ukuran kabel penghantar yang berbeda kemudian disimulasikan dengan menggunakan perangkat lunak ETAP 12.6.0. sampai ketemu hasil yang terbaik.

Tabel 2. Perbaikan Rugi-rugi Daya

\begin{tabular}{|c|c|c|c|}
\hline $\begin{array}{l}\text { NAMA } \\
\text { KABEL }\end{array}$ & $\begin{array}{c}\text { KONDISI AWAL } \\
(\mathrm{mm} 2)\end{array}$ & $\begin{array}{l}\text { RE-SIZING } 1 \\
(\mathrm{~mm} 2)\end{array}$ & $\begin{array}{c}\text { RE-SIZING } 2 \\
\text { (mm2) }\end{array}$ \\
\hline Cable 1 & Cu N2XSEBY (3X300) & Cu N2XSY 400mm (x3) & $\mathrm{Cu}$ N2XSY $400 \mathrm{~mm}(\mathrm{x} 3)$ \\
\hline Cable 2 & Cu N2XSEBY $(3 \mathrm{X} 300)$ & Cu N2XSY 400mm (x3) & Cu N2XSY 400mm (x3) \\
\hline Cable 3 & Cu N2XSEBY (3X120) & Cu N2XSEBY (3X150) & Cu N2XSEBY (3X185) \\
\hline Cable 4 & Cu N2XSEBY (3X240) & Cu N2XSEBY (3X300) & Cu N2XSEBY (3X400) \\
\hline Cable 5 & Cu N2XSEBY (3X240) & Cu N2XSEBY (3X300) & Cu N2XSEBY (3X400) \\
\hline Cable 6 & Cu N2XSEBY (3X240) & Cu N2XSEBY (3X300) & Cu N2XSEBY ( 3 X400) \\
\hline Cable 7 & Cu N2XSEBY (3X240) & Cu N2XSEBY (3X300) & Cu N2XSEBY ( 3 X400) \\
\hline Cable 8 & Cu N2XSEBY (3X240) & Cu N2XSEBY (3X300) & Cu N2XSEBY (3X400) \\
\hline Cable 9 & Cu N2XSEBY (3X240) & Cu N2XSEBY (3X300) & Cu N2XSEBY (3X400) \\
\hline Cable 10 & Cu N2XSEBY $(3 X 120)$ & Cu N2XSEBY (3X150) & Cu N2XSEBY (3X185) \\
\hline Cable 11 & Cu N2XSEBY (3X95) & Cu N2XSEBY (3X120) & Cu N2XSEBY (3X150) \\
\hline able 12 & Cu N2XSEBY (3X240) & Cu N2XSEBY (3X300) & Cu N2XSEBY (3X400) \\
\hline ble 13 & $\mathrm{Cu}$ N2XSEBY $(3 \mathrm{X} 240)$ & Cu N2XSEBY (3X300) & $\mathrm{Cu}$ N2XSEBY $(3 \mathrm{X} 400)$ \\
\hline
\end{tabular}

b. Hasil perbaikan rugi-rugi daya dan tegangan

Dari tabel 4 dapat dilihat rugi-rugi daya dan drop tegangan menurun sesuai dengan menurunnya resistansi kabel penghantar.

Tabel 4. Hasil Perbaikan Rugi-Rugi Daya

\begin{tabular}{|c|c|c|}
\hline Nama Kabel & Losses $(\mathrm{Kw})$ & $\%$ Vd drop in Vmag \\
\hline Cable 1 & 0.00 & 0.00 \\
\hline Cable 2 & 0.40 & 0.00 \\
\hline Cable 3 & 2.30 & 0.03 \\
\hline Cable 4 & 2.80 & 0.02 \\
\hline Cable 5 & 1.00 & 0.01 \\
\hline Cable 6 & 0.40 & 0.02 \\
\hline Cable 7 & 0.20 & 0.00 \\
\hline Cable 8 & 0.50 & 0.02 \\
\hline Cable 9 & 0.50 & 0.02 \\
\hline Cable 10 & 13.00 & 0.02 \\
\hline Cable 11 & 0.50 & 0.02 \\
\hline Cable 12 & 7.80 & 0.09 \\
\hline Cable 13 & 5.80 & 0.06 \\
\hline Total & $\mathbf{3 5 . 2 0}$ & $\mathbf{0 . 3 1}$ \\
\hline
\end{tabular}

\section{Langkah-Langkah Perbaikan Faktor Daya}

Simulasi akan dilakukan saat sebelum menambahkan kapasitor bank pada bus yang faktor dayanya rendah, setelah itu simulasi akan dilakukan setelah penambahan kapasitor bank pada bus tersebut.

a. Faktor daya jaringan eksisting 
Instalasi jaringan dengan beban $100 \%$ diuji menggunakan perangkat lunak ETAP 12.6.0 sehingga dihasilkan nilai faktor daya. Pada kondisi awal terdapat beberapa rel (bus), seperti terlihat pada tabel dibawah ini:

Tabel 3. Faktor Daya Kondisi Awal

\begin{tabular}{|l|c|c|}
\hline \multirow{2}{*}{ Bus } & \multicolumn{2}{|c|}{ Faktor Daya Kondisi Awal } \\
\cline { 2 - 3 } & Arus (A) & Faktor Daya \\
\hline TR 1.1 & 455,3 & 0.93 \\
\hline TR 1.2 & 455,5 & 0.93 \\
\hline BUS 36 & 362,2 & 0.89 \\
\hline TR L8 & 381,2 & 0.75 \\
\hline
\end{tabular}

Faktor daya paling bagus adalah faktor daya yang mendekati angka1. Adapun faktor daya yang diijinkan oleh PLN minimal 0,85.

b. Perbaikan faktor daya

Penambahan kapasitor di perlukan untuk memperbaiki faktor daya yang ada karena masih ada bus yang faktor dayanya dibawah 0,85, sehingga arus yang mengalirpun cukup tinggi. Pada sistem pemodelan ini penulis menambahkan 4 kapasitor bank dibagian sisi $20 \mathrm{kV}$ pada jaringn instalasi existing.

Daya yang mengalir pada bus TR 1.1 sebesar $19.581 \mathrm{~kW}$, Faktor daya awal sebelum penambahan kapasitor bank di bus trafo TR 1.1 adalah 0,93 , sedangkan faktor daya yang diinginkan di bus tersebut adalah 0,97 . sehingga ukuran kapasitor yang diperlukan 19.581 ( tg cos10,93 - tg cos-1 0,97 ) sama dengan 2839,2 kvar, Jadi kapasitor bank yang digunakan adalah kapasitor yang mempunyai kapasitas 3000 kvar.

Daya yang mengalir pada bus TR 1.2 sebesar $15.141 \mathrm{~kW}$, Faktor daya awal sebelum penambahan kapasitor bank di bus trafo TR 1.2 adalah 0,93, sedangkan faktor daya yang diinginkan di bus tersebut adalah 0,98 sehingga ukuran kapasitor yang diperlukan 15.141 ( tg cos-1 0,93 - $\operatorname{tg} \cos -10,98$ ) sama dengan 2649,6 kvar. Jadi kapasitor bank yang digunakan adalah kapasitor bank yang mempunyai kapasitas 3000 kvar.

Daya yang mengalir pada bus 36 sebesar $17.414 \mathrm{~kW}$, Faktor daya awal sebelum penambahan kapasitor bank di bus trafo TR 1.2 adalah 0,89 , sedangkan faktor daya yang diinginkan di bus tersebut adalah 0,94 sehingga ukuran kapasitor yang diperlukan 17.414 ( tg cos-1 0,89 - tg cos-1 0,94 ) sama dengan 2612,1 kvar. Jadi kapasitor bank yang digunakan adalah kapasitor bank yang mempunyai kapasitas 3000 kvar.

Daya yang mengalir pada bus TR L8 sebesar 8288 kW, Faktor daya awal sebelum penambahan kapasitor bank di bus trafo TR 1.2 adalah 0,75 , sedangkan faktor daya yang diinginkan di bus tersebut adalah 0,88 sehingga ukuran kapasitor yang diperlukan 8288 ( tg cos-1 0,75 - tg cos-1 0,88 ) sama dengan 2900,8 kvar. Jadi kapasitor bank yang digunakan adalah kapasitor bank yang mempunyai kapasitas 3000 kvar.

Tabel 4. Arus dan Faktor Daya

\begin{tabular}{|l|l|l|l|l|}
\hline \multirow{2}{*}{ Bus } & \multicolumn{2}{|c|}{ Sebelum Penambahan } & \multicolumn{2}{l|}{ Setelah Penambahan } \\
\cline { 2 - 5 } & Arus(A) & Faktor Daya & Arus (A) & Faktor Daya \\
\hline TR 1.1 & 455,3 & 0.93 & 431,4 & 0.97 \\
\hline TR 1.2 & 455,5 & 0.93 & 426,3 & 0.98 \\
\hline BUS 36 & 362,2 & 0.89 & 355,9 & 0.91 \\
\hline TR L8 & 381,2 & 0.75 & 345,9 & 0.93 \\
\hline
\end{tabular}

\section{Langkah Perbaikan Transien di bus 2}

Istilah transien sudah lama digunakan dalam tenaga listrik sebagai sesuatu kejadian yang sebenarnya tidak diinginkan dan sifatnya sangat cepat, namun merupakan suatu kejadian yang alami sehingga tidak dapat dicegah. Kondisi transien dapat berupa tegangan ataupun arus. 


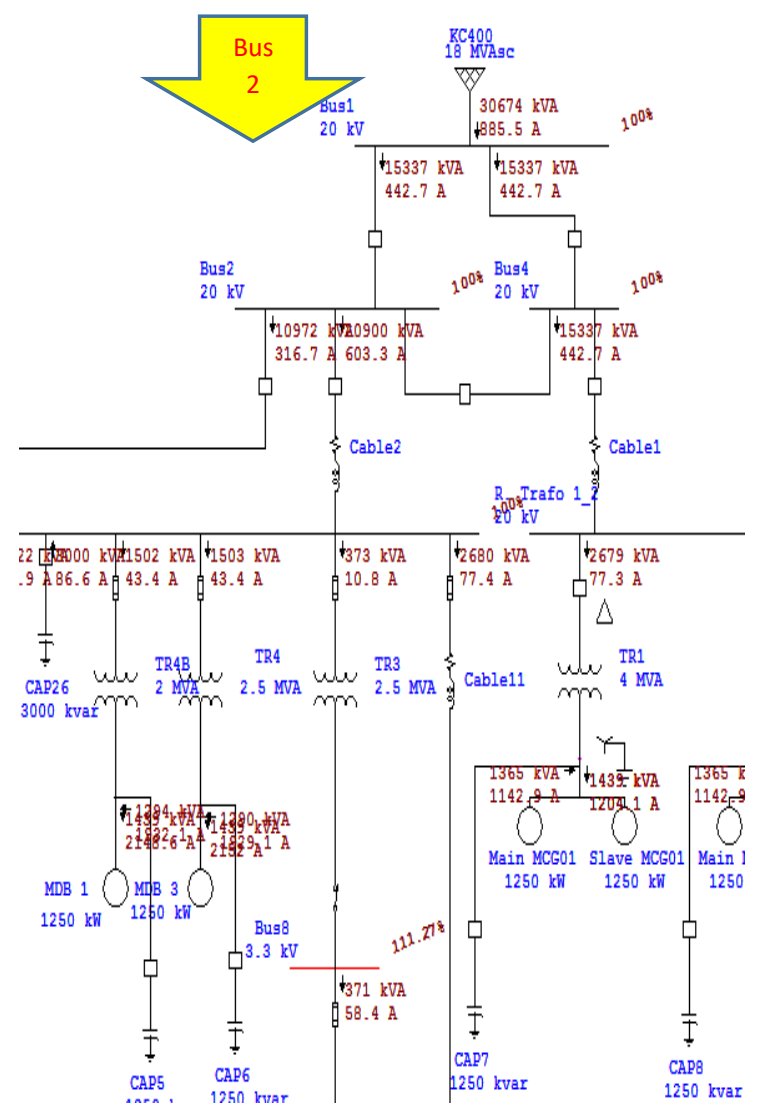

Gambar 7. Pemodelan Gangguan di Bus 2

Transien yang terjadi saat gangguan bisa dikurangi dengan menambahkan reaktor pada sisi bus yang mempunyai potensi besar terkena gangguan transien. Seperti transien yang diakibatkan oleh sambaran petir.

Untuk mengetahui berapa besar arus dan tegangan yg melewati sebuah bus pada jaringan tegangan menengah $20 \mathrm{kV}$ plant $\mathrm{M}$ ketika terjadi gangguan transien, penulis membuat skenario gangguan pada bus 2 . Seakan-akan gangguan transien itu terjadi pada bus 2, sehingga dengan begitu kita dapat membandingkan tegangan yang mengalir di bus 2 sebelum penambahan reaktor dan setelah penambahn reaktor dengan menggunakan simulasi ETAP 12.6.0.

a. Tegangan di bus 2 sebelum penambahan reactor

Pada kondisi ini kita anggap terjadi gangguan 3 fasa ke tanah, proses simulasi selama $t=0,600$ detik. Tegangan transien pada bus 2 seperti terlihat pada gambar dibawah ini:

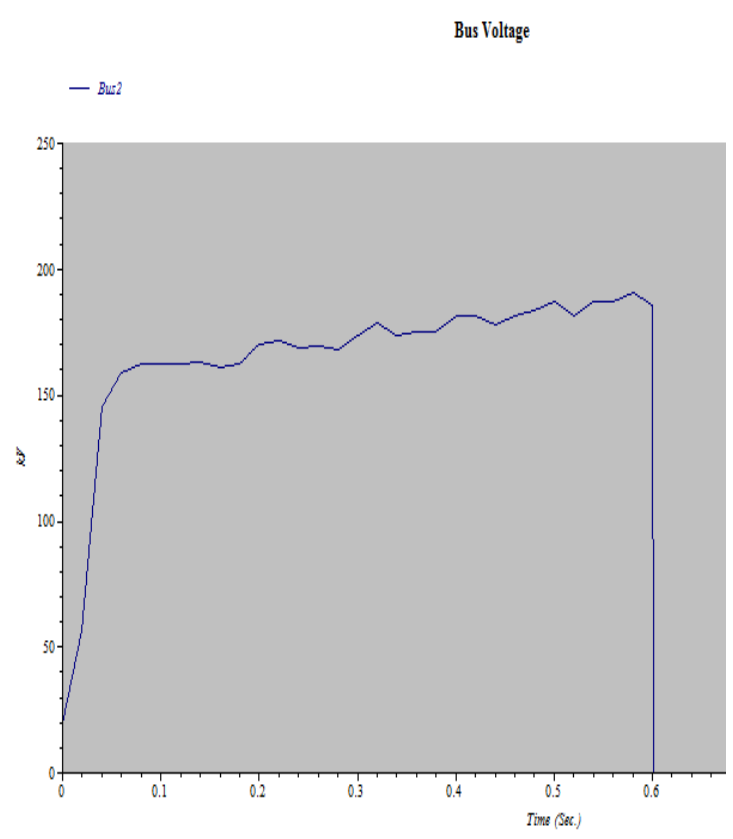

Gambar 8. Tegangan Transient di Bus 2 Sebelum Penambahan Reaktor

b. Tegangan di bus 2 setelah penambahan reaktor

Pada kondisi ini kita anggap terjadi gangguan 3 fasa ke tanah, dengan proses simulasi selama $\mathrm{t}=$ 0,500 detik. Tegangan transien pada bus 2 setelah penambahan reaktor seperti terlihat pada gambar dibawah ini:

Bus Voltage

$-B$ su2

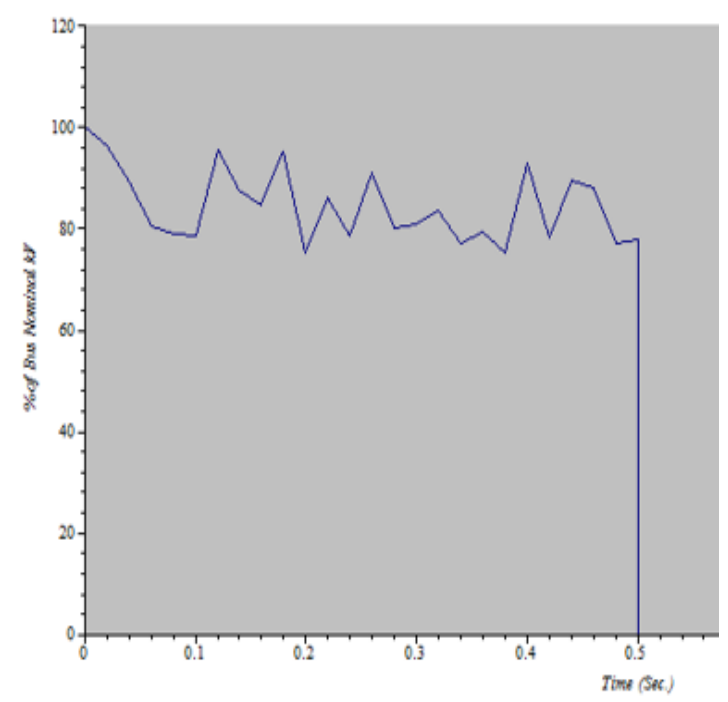

Gambar 9. Tegangan Transient di Bus 2 Setelah Penambahan Reaktor

Langkah Perbaikan Transien Di Bus 4 Pada kondisi normal saat beban penuh 
Sumber dari KC 400 menyuplai tegangan sebesar $20 \mathrm{kV}, 30.283 \mathrm{kVA}$ dan arus 885,5A. Daya pada bus 4 dalam keadaan beban $100 \%$ sebesar 15.337 kVA dengan arus yang mengalir sebesar 442,7A.

Untuk mengetahui berapa besar arus dan tegangan yg melewati sebuah bus pada jaringan tegangan menengah $20 \mathrm{kV}$ plant $\mathrm{M}$ ketika terjadi gangguan transien, penulis membuat skenario gangguan pada bus 4 . Seakan-akan gangguan transien itu terjadi pada bus 4, sehingga dengan begitu kita dapat membandingkan tegangan yang mengalir di bus 4 sebelum penambahan reaktor dan setelah penambahn reaktor dengan menggunakan simulasi ETAP 12.6.0.

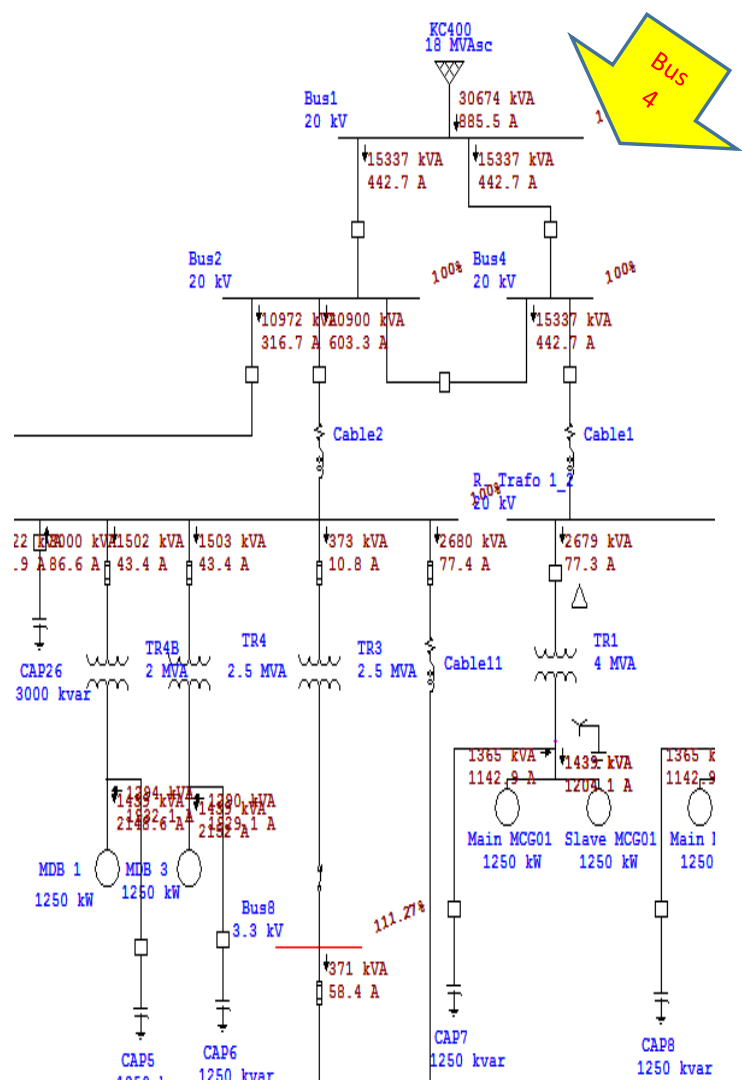

Gambar 9. Pemodelan Gangguan di Bus 4 a. Tegangan di bus 4 sebelum penambahan reaktor

Pada kondisi ini kita anggap terjadi gangguan 3 fasa ke tanah, proses simulasi selama $t=0,600$ detik. Tegangan transien pada bus 4 seperti terlihat pada gambar dibawah ini:

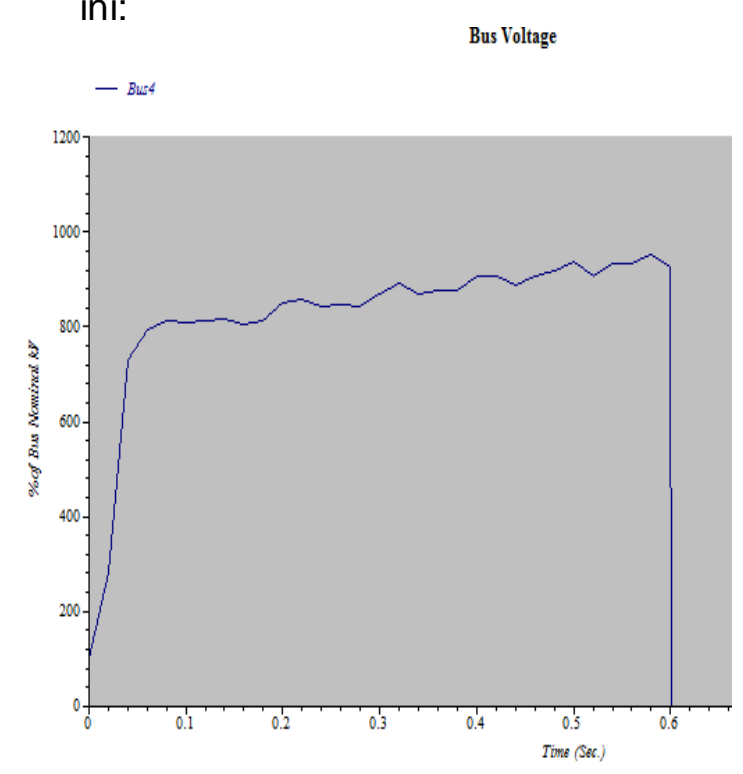

Gambar 10. Tegangan Transient di Bus 4 Sebelum Penambahan Reaktor

b. Tegangan di bus 4 setelah penambahan reaktor

Pada kondisi ini kita anggap terjadi gangguan 3 fasa ke tanah sehingga CB (Circuit Breaker) dalam keadaan terbuka dengan proses simulasi selama $t=0,600$ detik. Tegangan transien pada bus 4 seperti terlihat pada gambar dibawah ini: 


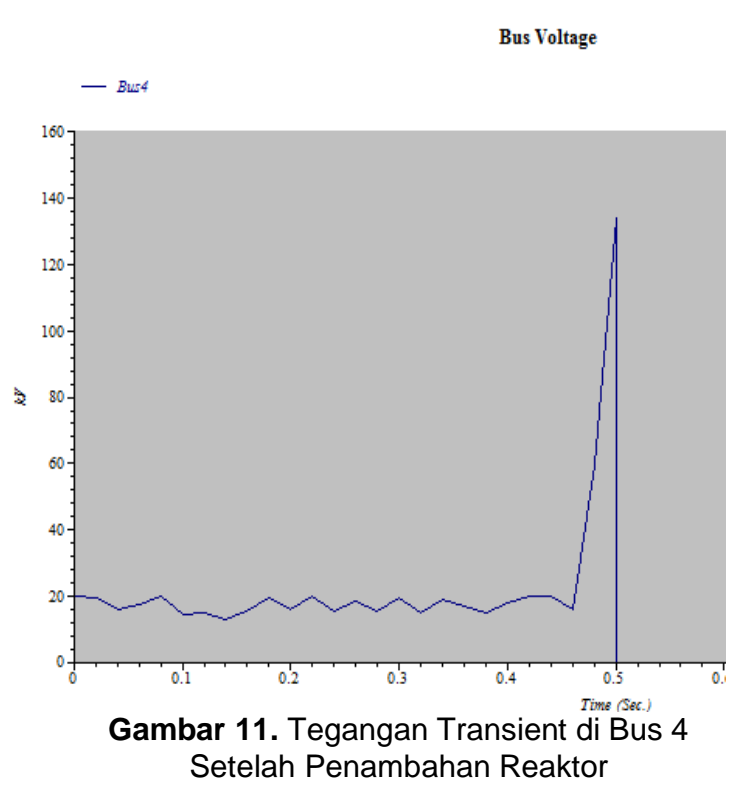

\section{KESIMPULAN}

Pengujian yang di lakukan dengan menggunakan perangkat lunak (Software) ETAP 12.6 .0 adalah sebagai berikut:

a. Rugi rugi daya terkecil didapat saat resizing ke-2. Setelah dilakukan re-sizing ke-2 ketika beban 100\% tingkat rugirugi daya menunjukan $35,20 \mathrm{~kW}$. Lebih baik dari kondisi sebelumnya yang menunjukan nilai 53, $60 \mathrm{~kW}$. Pada saat re-sizing ke-2 rugi-rugu daya turun menjadi $18,4 \mathrm{~kW}$, turun sebesar $52,3 \%$ bila dibandingkan sebelum dilakukan re-sizing.

b. Tegangan jatuh terkecil didapat saat re-sizing ke-2. Setelah dilakukan resizing ke-2 pada kondisi beban 100\% tegangan jatuh menunjukan nilai $0,31 \%$, bila dibandingkan dengan kondisi awal tegangan jatuh menunjukan nilai $0,57 \%$, setelah $r e$ sizing ke-2 tegangan jatuhnya turun menjadi $0,26 \%$ atau turun $45,6 \%$ bila dibandingkan sebelum dilakukan resizing.

c. Penambahan kapasitor bank sebanyak 4 buah, ,masing-masing 3000 kvar di trafo 1-1, trafo $1-2$, bus 36 dan trafo $L 8$ dapat memperbaiki faktor daya pada bus-bus yang mengalami under voltage. Sebelum penambahan kapasitor bank rata-rata faktor daya sebesar 0,88, tetapi setelah penambahan kapasitor bank, faktor daya mengalami kenaikan menjadi
0,95. Ada perbaikan faktor daya sebesar 0,07 . Faktor daya mengalami perbaiakan/kenaikan sebesar 7,95\%.

d. Sebelum penambahan reaktor di bus 2, tegangan yang mengalir di bus tersebut menunjukan nilai $190 \mathrm{kV}$, tetapi setelah penambahan reaktor tegangan yang melewati bus 2 turun menjadi $100 \mathrm{kV}$. Ada penurunan tegangan sebesar 90 $\mathrm{kV}$. Tegangan yang mengalir saat terjadi transien di bus 2 mengalami penurunan sebesar $47,4 \%$ setelah penambahan reaktor.

e. Sebelum penambahan reaktor di bus 4 , tegangan yang mengalir di bus tersebut menunjukan nilai $900 \mathrm{kV}$, tetapi setelah penambahan reaktor tegangan yang melewati bus 4 turun menjadi $140 \mathrm{kV}$. Ada penurunan tegangan sebesar 760 $\mathrm{kV}$. Tegangan yang mengalir saat terjadi transien di bus 4 mengalami penurunan sebesar $542.8 \%$ setelah penambahan reaktor.

f. Simulasi yang dilakukan berdasarkan standar ANSI. Hasil perbaikan sudah dianggap cukup berdasarkan rekomendasi NEC dan PUIL 2011.

\section{DAFTAR PUSTAKA}

1. Luces M. Faulkenberry and Walter Coffer, "Electrical Power Distribution and Transmission", Prentice Hall, 1996.

2. William D. dan Stevenson Jr., "Elements of Power System Analysis $4^{\text {th }}$ Edition", McGraw-Hill, 1982.

3. Saadat, H, "Powers System Analysis", Mc Graw Hill, 1999

4. Taczi and I. Vokony, "Composition of inertial response emulation mechanisms for power system frequency stability analysis," 2017 6th International Youth Conference on Energy (IYCE), Budapest, Hungary, 2017.

5. https://duniatehnikku.wordpress.com/20 11/01/17/cara-menghitung-kebutuhankapasitor-bank/

6. Beaty, H., W.," Handbook of Eletric Power Calulation", Mc. Graw Hill, 2001

7. Eray Aydin; Abdullah Polat; Lale T. Ergene "Vector control of DFIG in wind power applications and analysis for voltage drop condition" 2016 
National Conference on Electrical, Electronics and Biomedical Engineering (ELECO).

8. https://dunialistrik.blogspot.co.id/2010/03/kualitasdaya-listrik-power-quality 